\title{
PENGANALISIS KESEGARAN DAGING SAPI DAN DAGING BABI MENTAH BERDASARKAN KLASIFIKASI WARNA DAN KELEMBABAN
}

\author{
Nadya Ayu Nafiasari ${ }^{1}$ dan Ariesta Martiningtyas Handayani ${ }^{*}$ \\ ${ }^{1}$ Teknik Elektro dan Informatika \\ Sekolah Vokasi Universitas Gadjah Mada
}

Submisi: 20-05-2018; Revisi: 11-08-2018; Diterima:12-08- 2018

\begin{abstract}
There are many frauds involving the trade of beef. Traders do the fraud by replacing the beef they sell with pork. Also, the lack of consumer knowledge about the difference between beef and pork make these traders unscrupulous. Thus, in this research we designed and created systems that can identify and analyze the freshness of beef and pork. This system uses a color sensor as a color identifier in meat and humidity sensors to measure the freshness level of meat. Also used is a microcontroller as data acquirer and processor. This system is designed to distinguish between beef and pork. This study involved 420 data of beef and pork. These data have shown that this system has an accuracy of $79 \%$, $80 \%, 80 \%, 83 \%, 77 \%$ and $81 \%$ in identifying fresh beef, fresh pork, less fresh beef, less fresh pork, non fresh beef, and non fresh pork consecutively. This system is portable because it can be taken anywhere with a battery that supplies power. With this system, consumers can distinguish between beef and pork and know the meat freshness level.
\end{abstract}

Keywords: Color sensor; Freshness; Humidity sensor; Microcontroller; Portable.

\begin{abstract}
ABSTRAK
Banyak terjadi penipuan yang melibatkan perdagangan daging sapi. Penipuan tersebut dilakuan para pedagang dengan mengganti daging sapi yang dijualnya dengan daging babi. Kurangnya pengetahuan konsumen terhadap perbedaan daging sapi dan daging babi membuat para oknum pedagang ini semakin bertambah. Oleh karena itu, kami melakukan penelitian dengan merancang dan membuat sistem yang dapat mengidentifikasi dan menganalisis kesegaran daging sapi dan daging babi. Sistem ini menggunakan sensor warna sebagai pengidentifikasi warna pada daging dan sensor kelembaban untuk mengukur tingkat kesegaran daging. Selain itu digunakan juga sebuah mikrokontroler sebagai pengakuisisi dan pengolah data. Sistem ini dirancang untuk dapat membedakan antara daging sapi dan daging babi. Penelitian ini melibatkan pengambilan data pada daging sapi maupun daging babi sebanyak 420 data. Data-data tersebut menunjukkan bahwa sistem ini memiliki akurasi sebesar $79 \%$, $80 \%, 80 \%, 83 \%, 77 \%$, dan $81 \%$ dalam mengidentifikasi daging sapi segar, daging babi segar, daging sapi kurang segar, daging babi kurang segar, daging sapi tidak segar, dan daging babi tidak segar secara berurutan. Sistem ini bersifat portabel karena dapat dibawa kemana saja dengan dilengkapi baterai yang mensuplai daya alat ini. Dengan adanya sistem ini, konsumen dapat membedakan antara daging sapi dan daging babi serta dapat mengetahui tingkat kesegaran pada setiap daging.
\end{abstract}

Kata kunci: Kesegaran; Mikrokontroler; Portable; Sensor kelembaban; Sensor warna.

${ }^{*}$ Corresponding author: nadya.ayune@gmail.com

Copyright @ 2018 THE AUTHOR(S).This article is distributed under a Creative Commons Attribution-Share Alike 4.0 International license. 


\section{PENGANTAR}

Daging merupakan bahan makanan hewani yang dibutuhkan oleh manusia. Terdapat berbagai macam jenis bahan makanan daging. Mereka adalah daging sapi, kambing, ikan, unggas, babi, dan sebagainya. Harga daging babi lebih murah dibandingkan dengan daging sapi. Perbedaan harga antara kedua daging tersebut menyebabkan munculnya praktik penipuan pada perdagangan daging sapi. Penipuan tersebut berupa penggantian sebagian atau seluruh daging sapi menjadi daging babi. Oleh karena itu, dibutuhkan suatu sistem yang dapat membedakan antara daging mentah sapi dan babi. Kualitas daging sapi dapat diidentifikasi berdasarkan warna dan bau, sehingga identifikasi kualitas daging sapi menggunakan sensor gas dan sensor warna.

Pemanfaatan sensor gas dan sensor warna juga dilakukan untuk identifikasi kondisi kesegaran daging. Hal tersebut dilakukan dengan menguji daging tersebut menggunakan tiga kondisi. Kondisi-kondisi tersebut terdiri dari daging segar, daging agak busuk, dan daging busuk. Penggunaan ketiga buah sensor gas dan sensor warna telah berhasil mendapatkan pola yang khusus untuk setiap tingkat kesegaran daging yang diuji. Dari hasil pengujian terhadap tiga buah sampel yang mewakili tingkat kesegaran daging diperoleh tingkat keberhasilan dalam proses identifikasi mencapai $80 \%$.

Hal yang sama juga telah dilakukan untuk mengukur tingkat kesegaran daging dengan menggunakan sensor warna. Sistem pengukuran tersebut dapat mengetahui nilai RGB pada sampel daging yang diidentifikasi dan membandingkan dengan komposisi warna RGB daging sebagai acuan. Hasil penelitian ini menunjukkan bahwa daging sapi segar memiliki nilai $G$ dan $B$ yang saling mendekati yaitu masing-masing 3- 38 dan 3-29 untuk G dan 4-27 dan 4-25 untuk B yang membedakan hanya nilai $R$, yaitu nilai $R$ terbesar yaitu 58 .

Hal yang sama juga telah dilakukan untuk mengukur tingkat kualitas daging sapi dengan menggunakan sensor warna (TCS3200), sensor bau (TGS2602), serta sensor pH. Data yang diterima oleh sensor kemudian dikirim ke mikrokontroler untuk di proses. Mikrokontroler yang digunakan adalah Arduino UNO. Hasil pengolahan yang dilakukan di mikrokontroler ditampilkan pada LCD dan indicator LED. Dari hasil pengujian dapat disimpulkan bahwa alat yang telah dibuat dapat mendeteksi kualitas daging sapi bagian has dalam.

Perbedaan daging sapi dan daging babi dapat diketahui dari karakteristiknya. Karakteristik dapat dilihat dari warna, serat, tekstur dan aroma daging. Dari segi warna daging babi cenderung lebih pucat dari pada daging sapi. Dari serat daging sapi lebih jelas terlihat dari pada daging babi.

Rancangan elektronis dapat dilihat pada Gambar 1. Sensor TCS3200 dan YL-69 berperan pada pengambilan data yang akan diolah pada Mikrokontroler. Sensor TCS3200 merupakan sensor warna. Sedangkan sensor YL-96 merupakan sensor kelembaban. Kedua sensor terhubung oleh Mikrokontroler. Mikrokontroler yang digunakan adalah Arduino UNO. Mikrokontroler terhubung dengan Character LCD Module yang digunakan untuk menampilkan jenis dan kesegaran daging.

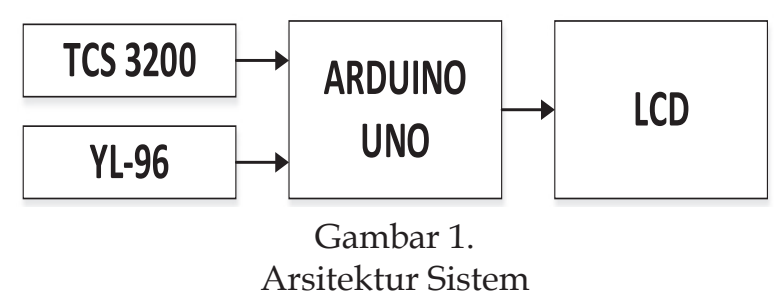

Gambar 2 menunjukkan flowchart algoritme utama. Proses awal dimulai dari LCD menampilkan dua Fitur utama. Fitur tersebut antara lain fitur training dataset daging dan fitur identifikasi jenis dan kesegaran daging.

Identifikasi jenis dan kesegaran daging dapat memiliki akurasi yang baik maka diperlukan Training sampel. Training sampel tersebut terdiri dari Training sampel daging sapi dan daging babi. Training Sampel masing-masing daging tersebut diawali dari pengumpulan data yang merupakan luaran dari eksperimen penentuan karakteristik warna yang diwakili oleh Tiga warna. Tiga warna tersebut terdiri dari Red, Green, dan Blue (RGB). Selanjutnya nilai kesegaran daging 
sapi didapat dari kelembaban daging yang diukur menggunakan sensor kelembaban (YL-96). Eksperimen dilakukan dengan cara mengambil data kelembaban dari daging hari pertama hingga hari ke tujuh. Pengambilan data dilakukan sebanyak 15 kali dari setiap daging. Bagan alir training sampel masingmasing daging dapat dilihat pada Gambar 2. Setelah Training sampel dilakukan, maka diperoleh set point yang dapat digunakan untuk mengidentifikasi jenis daging. Hasil identifikasi tersebut ditampilkan pada LCD.

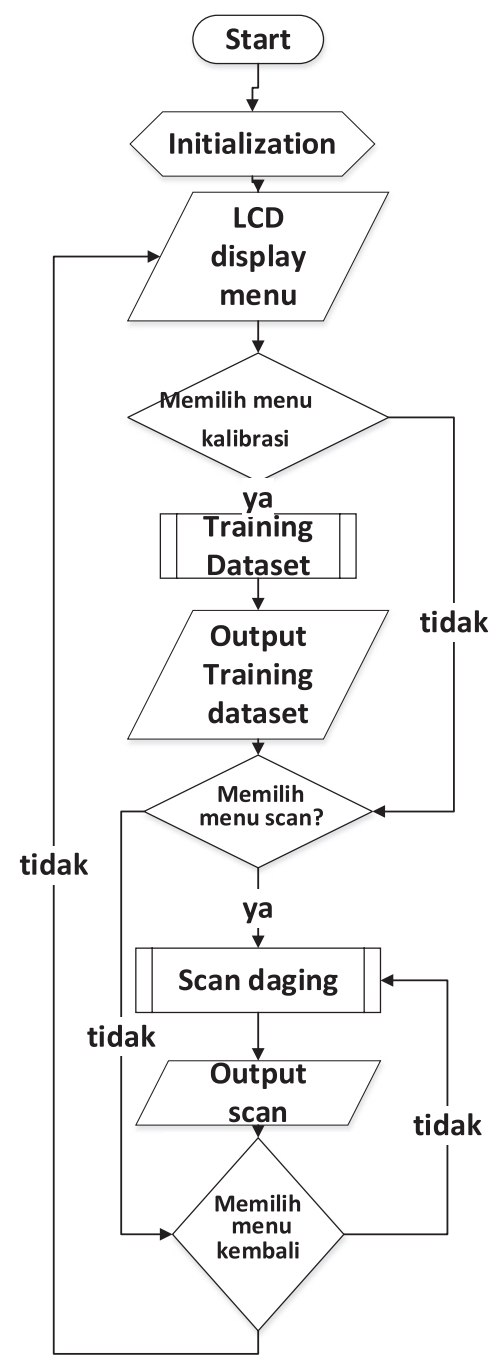

(a)

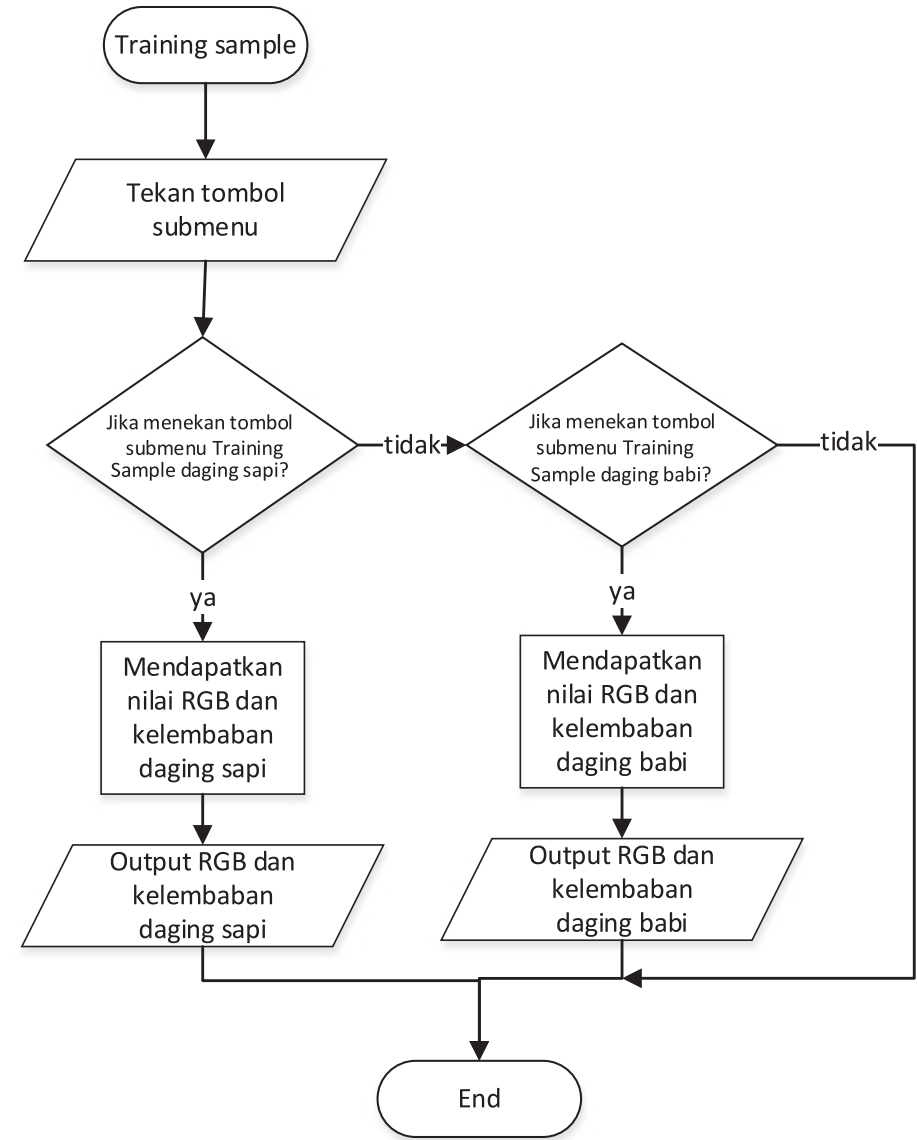

(b)

Gambar 2.

Flowchart (a) program utama. (b) Flowchart training Sampel daging 


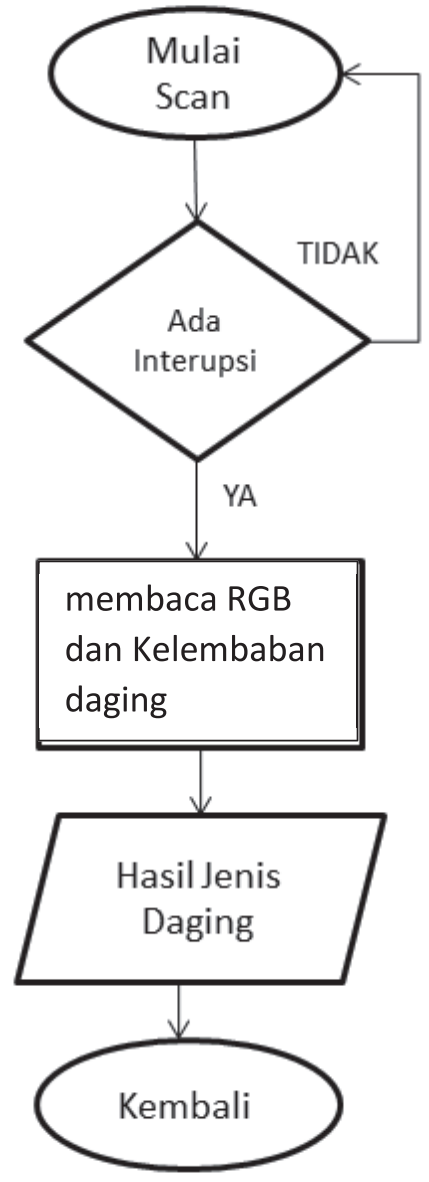

Gambar 3.

Flowchart Sub Program Scan daging

Menu scan berfungsi sebagai mengidentifikasi jenis daging yang belum di ketahui. Identifikasi daging dilakukan dengan pembacaan RGB dan kelembaban daging yang kemudian dicocokkan dengan nilai setpoint. Hasil pembacaan dan identifikasi jenis daging dapat dilihat pada LCD.

\section{HASIL DAN PEMBAHASAN}

Implementasi dari rancangan tersebut ditunjukkan pada Gambar 4. Shield board arduino, sensor, dan LCD dicetak pada PCB.

Training sampel pada daging diawali dari pengumpulan data yang merupakan luaran dari eksperimen penentuan karakteristik warna yang diwakili nilai RGB. Dari 15 data tersebut diambil nilai rata-rata dari setiap data Red, Green, dan Blue. Dengan merujuk dari hasil

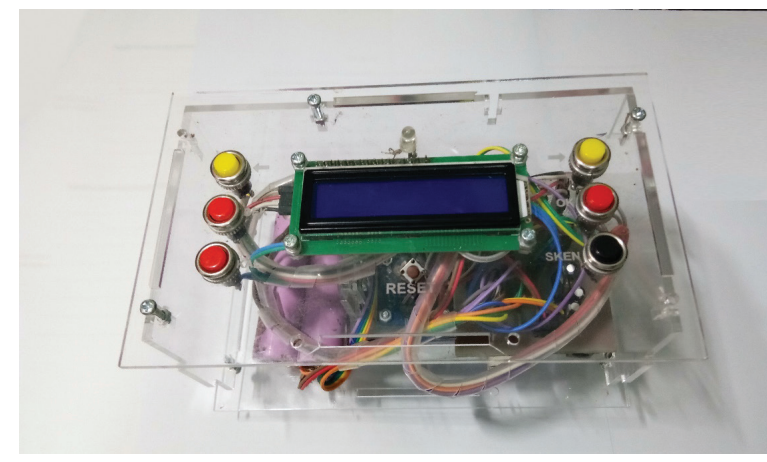

Gambar 4.

Implementasi Alat

eksperimen penentuan karakteristik warna, dibuat 6 (enam) klasifikasi kondisi setiap daging. Klasifikasi tersebut antara lain adalah:

1. Daging Sapi Segar yaitu daging sapi dalam rentang jangka waktu 1-2 hari dengan nilai RGB ( $R=58.8, G=104.13, B=86.261)$.

2. Daging Babi Segar yaitu daging babi dalam rentang jangka waktu 1-2 hari dengan nilai RGB ( $R=69, \mathrm{G}=139.87, \mathrm{~B}=113.93$ ).

3. Daging Sapi Kurang Segar yaitu daging sapi dalam rentang jangka waktu 3-5 hari dengan nilai RGB ( $\mathrm{R}=118-124.4, \mathrm{G}=161.2-$ 178.53, B=134.87-144.6).

4. Daging Babi Kurang Segar yaitu daging babi dalam rentang jangka waktu 3-5 hari dengan nilai $R G B(R=105.93-115, G=129.73-$ 142.4, B=108.6-114.9).

5. Daging Sapi Tidak segar yaitu daging sapi dalam rentang jangka waktu 6-7 hari dengan nilai RGB ( $R=119.67, G=133.47$ 170.6, B=184.73 - 149.27).

6. Daging Babi Tidak segar yaitu daging babi dalam rentang jangka waktu 6-7 hari dengan nilai RGB ( $R=113, G=114.47-105$, $\mathrm{B}=149.33-128.8$ ).

Eksperimen dilakukan pada daging sapi dan daging babi. Dari 15 data tersebut diambil nilai rata-rata dari setiap data kelembaban. Data yang dihasilkan berupa Luaran sensor yang dikonversikan ke dalam data digital dengan resolusi 10 bit dari sensor YL-96. Data digital tersebut jika diubah kedalam bentuk desimal maka nilai tersebut akan berada dalam rentang 0-1023. Data kelembaban daging sapi ditunjukkan pada Tabel 1. 
Tabel 1.

Data kelembaban daging sapi

\begin{tabular}{l|l|l|l|l|l|l|l}
\hline \multicolumn{1}{c|}{ NO } & \multicolumn{1}{c|}{ Hari 1 } & \multicolumn{1}{c|}{ Hari 2 } & \multicolumn{1}{c}{ Hari 3 } & \multicolumn{1}{c}{ Hari 4 } & Hari 5 & Hari 6 & Hari 7 \\
\hline 1 & 138 & 112 & 63 & 111 & 125 & 136 & 105 \\
\hline 2 & 367 & 130 & 58 & 118 & 124 & 127 & 101 \\
\hline 3 & 416 & 114 & 78 & 122 & 145 & 136 & 98 \\
\hline 4 & 391 & 120 & 83 & 125 & 125 & 125 & 98 \\
\hline 6 & 432 & 133 & 82 & 122 & 122 & 122 & 99 \\
\hline 7 & 457 & 141 & 80 & 120 & 125 & 120 & 99 \\
\hline 8 & 460 & 148 & 73 & 118 & 122 & 117 & 101 \\
\hline 9 & 502 & 153 & 82 & 119 & 119 & 111 & 102 \\
\hline 10 & 471 & 173 & 81 & 117 & 120 & 108 & 103 \\
\hline 12 & 458 & 184 & 80 & 119 & 118 & 109 & 105 \\
\hline 13 & 451 & 191 & 96 & 114 & 117 & 108 & 108 \\
\hline 14 & 430 & 151 & 75 & 117 & 115 & 105 & 112 \\
\hline 15 & 414 & 143 & 89 & 114 & 113 & 99 & 114 \\
\hline Rata-rata & 415.06 & 143.2 & 81.9 & 118.06 & 120.8 & 114.7 & 105.6 \\
\hline & & 125 & 126 & 117 & 112 & 99 & 122 \\
\hline
\end{tabular}

Pada Tabel 1, tercatat bahwa nilai yang dihasilkan mengalami penurunan nilai pada setiap sampel daging berdasarkan hari. Data kelembaban daging sapi pada hari pertama memiliki rata-rata sebesar 415.06. Data kelembaban pada hari kedua naik menjadi 143.2. Akan tetapi, pada hari ketiga data kelembaban mengalami penurunan hingga 81.9. Data kelembaban daging sapi terus menurun tingkat kelembabannya. Hal ini dikarenakan kadar air dalam daging sapi berkurang. Tabel 2 adalah hasil pengambilan data kesegaran daging babi.

Tabel 2.

Data kelembaban daging babi

\begin{tabular}{l|l|l|l|l|l|l|l}
\hline NO & \multicolumn{1}{|c|}{ Hari 1 } & \multicolumn{1}{c}{ Hari 2 } & \multicolumn{1}{c}{ Hari 3 } & \multicolumn{1}{c}{ Hari 4 } & \multicolumn{1}{c}{ Hari 5 } & Hari 6 & Hari 7 \\
\hline 1 & 335 & 112 & 63 & 111 & 125 & 136 & 105 \\
\hline 2 & 347 & 130 & 58 & 118 & 124 & 127 & 101 \\
\hline 3 & 408 & 114 & 78 & 122 & 145 & 136 & 98 \\
\hline 4 & 403 & 120 & 83 & 125 & 125 & 125 & 98 \\
\hline 5 & 387 & 133 & 82 & 122 & 122 & 122 & 99 \\
\hline 6 & 323 & 141 & 80 & 120 & 125 & 120 & 99 \\
\hline 7 & 364 & 148 & 73 & 118 & 122 & 117 & 101 \\
\hline 8 & 360 & 153 & 82 & 119 & 119 & 111 & 102 \\
\hline 10 & 350 & 173 & 81 & 117 & 120 & 108 & 103 \\
\hline 12 & 463 & 184 & 80 & 119 & 118 & 109 & 105 \\
\hline 13 & 423 & 191 & 96 & 114 & 117 & 108 & 108 \\
\hline 14 & 406 & 151 & 75 & 117 & 115 & 105 & 112 \\
\hline 15 & 300 & 143 & 89 & 114 & 113 & 99 & 114 \\
\hline Rata-rata & 295 & 125 & 126 & 117 & 112 & 99 & 122 \\
\hline
\end{tabular}


Pada data kelembaban terhadap daging babi dan daging babi, tercatat bahwa nilai yang dihasilkan mengalami penurunan nilai pada setiap sampel daging berdasarkan hari. Hal ini dikarenakan kadar air dalam daging sapi berkurang. Kemudian dengan terjadinya penurunan kelembaban daging tersebut, daging juga mengalami perubahan yang cukup drastis yaitu berubah menjadi lebih padat. Data kelembaban daging sapi dan daging babi dapat dilihat pada Gambar 5.

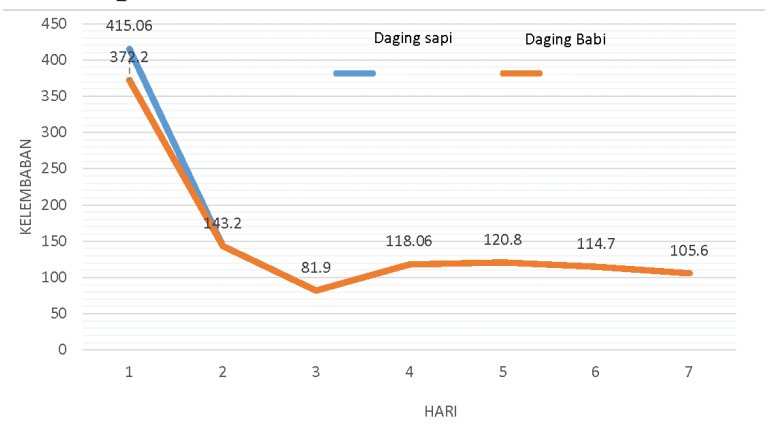

Gambar 5.

Perbandingan Kesegaran Daging

Dari pengambilan data dari eksperimen penentuan karakteristik warna dan kelembaban daging, maka dapat disimpulkan bahwa untuk mendapatkan nilai range yang baik dan stabil dilakukan sebuah metode scoring. Metode scoring system dilakukan dengan cara melihat data yang sangat berbeda dan signifikan terhadap penentuan perbedaan di setiap daging.

Rumus dari Scoring system pada sistem ini adalah:

Score $=(G r-B l)-(B l-R d)+G r+\frac{(\text { Freshness })}{3}$

Dimana:

Gr $\quad=$ Green

$\mathrm{Bl} \quad=$ Blue

Rd $\quad=$ Red

Freshnes $=$ Kesegaran daging sapi atau babi.

Scoring system memerlukan suatu norma pembanding agar dapat diinterpretasikan secara kualitatif. Pada dasarnya interpretasi scoring system selalu bersifat normatif, artinya makna skor diacukan pada posisi relatif skor dalam suatu kelompok yang telah dibatasi terlebih dahulu.
Tiap nilai hasil eksperimen tersebut kemudian dimasukkan ke dalam persamaan Scoring system, dilanjutkan dengan pencarian nilai terendah dan tertinggi untukmenghasilkan 6 (enam) range kategori. Kategori tersebut antara lain:

1. Daging Sapi Segar memiliki range nilai scoring 208 hingga 280.

2. Daging Babi Segar memiliki range nilai scoring 290 hingga 350.

3. Daging Sapi Kurang Segar memiliki range nilai scoring 90 hingga 150.

4. Daging Babi Kurang Segar memiliki range nilai scoring 155 hingga 200.

5. Daging Sapi Tidak Segar memiliki range nilai scoring 460 hingga 500.

6. Daging Babi Tidak Segar memiliki range nilai scoring 380 hingga 450 .

Jumlah prediksi yang benar dan tidak benar dari sebuah model yang dibandingkan dengan klasifikasi yang sebenarnya dalam data uji dapat diperoleh dengan menggunakan confusion matrix. Confusion matrix digunakan untuk menghitung nilai akurasi.

Confusion matriks membentuk matriks n-ke-n, di mana $\mathrm{n}$ adalah jumlah kelas. Masukan dari confusion matrix terdiri dari:

- True Positive (TP), yaitu jumlah objek yang benar merupakan daging sapi segar.

- False Positive (FP), yaitu hasilyang terpenuhi, ketika sebenarnya tidak terpenuhi.

- False Negative (FN), yaitu ketika mengindikasi gagal, tetapi seharusnya berhasil.

- True Negative (TN), yaitu jumlah objek yang tidak boleh terdeteksi dengan benar tidak terdeteksi

Akurasi (AC) adalah proporsi jumlah prediksi yang benar. Penghitungan keakuratan pendeteksian dilakukan menggunakan persamaan 2 .

$$
\text { Akurasi }=\frac{T P+T N}{T P+F P+F N+T N}
$$

Pengujian pendeteksian terhadap daging sapi dan babi bermaksud untuk mengetahui apakah alat ini dapat berhasil mendeteksi setiap daging yang di identifikasi. Setelah melalui pengambilan data dan menentukan range 
nilai pada masing-masing kondisi. Pengujian ini menggunakan parameter jenis kesegaran bertujuan untuk mencari nilai yang terbaik. Variasi nilai jenis kesegaranyang akan diujikan meliputi 6 (enam) macam, yaitu daging sapi segar, daging babi segar, daging sapi kurang segar, daging babi kurang segar, daging sapi tidak segar, dan daging babi tidak segar. Variasi yang sudah ditentukan akan dilakukan 5 (lima) kali ujicoba, kondisi yang diatur untuk pendeteksian ini adalah pencahayaan yang cukup dan stabil tanpa ada perubahan yang drastis. Hasil pengujian daging sapi segar akan ditunjukkan pada Tabel 3.

Tabel 3.

Hasil Pengujian Pendeteksian Daging Sapi

\begin{tabular}{l|l|l|l|l}
\multicolumn{5}{c}{ Segar } \\
\hline $\begin{array}{c}\text { Ujicoba } \\
\text { Ke- }\end{array}$ & $\begin{array}{c}\text { True } \\
\text { Positive }\end{array}$ & $\begin{array}{c}\text { False } \\
\text { Positive }\end{array}$ & $\begin{array}{c}\text { False } \\
\text { Negative }\end{array}$ & $\begin{array}{c}\text { True } \\
\text { Negative }\end{array}$ \\
\hline 1 & 1 & 0 & 0 & 5 \\
\hline 2 & 1 & 1 & 1 & 3 \\
\hline 3 & 0 & 1 & 1 & 4 \\
\hline 4 & 1 & 1 & 0 & 4 \\
\hline 5 & 1 & 1 & 1 & 3 \\
\hline Jumlah & 4 & 4 & 3 & 19 \\
\hline
\end{tabular}

Tabel 3 menunjukkan jumlah dari true positive adalah 4 (empat), jumlah false positif adalah 4 (empat), jumlah false negative adalah 4 (empat) dan true negative adalah 19, sehingga dapat dimasukkan nilai tersebut kedalam tabel confusion matrix. Confusion matrix digunakan untuk menghitung nilai akurasi. Tabel confusion matrix dapat dilihat pada Tabel 4 .

Tabel 4.

Confusion Matrix Daging Sapi Segar

\begin{tabular}{l|l|l|l}
\hline \multicolumn{2}{c|}{ Negatif } & \multicolumn{2}{c}{ Prediksi } \\
\cline { 3 - 4 } \multicolumn{2}{c|}{} & \multicolumn{2}{c}{ Positif } \\
\hline \multirow{2}{*}{ Aktual } & Negatif & 19 & 3 \\
\cline { 2 - 4 } & Positif & 3 & 4 \\
\hline
\end{tabular}

Maka nilai akurasi dari daging sapi segar:

Akurasi $=\frac{4+19}{4+3+3+19}$

Akurasi $=0.79$

Akurasi $=79 \%$
Tabel 5.

Hasil Pengujian Pendeteksian Daging Babi Segar

\begin{tabular}{l|l|l|l|l}
\hline $\begin{array}{c}\text { Ujicoba } \\
\text { Ke- }\end{array}$ & $\begin{array}{c}\text { True } \\
\text { Positive }\end{array}$ & $\begin{array}{c}\text { False } \\
\text { Positive }\end{array}$ & $\begin{array}{c}\text { False } \\
\text { Negative }\end{array}$ & $\begin{array}{c}\text { True } \\
\text { Negative }\end{array}$ \\
\hline 1 & 1 & 0 & 0 & 5 \\
\hline 2 & 1 & 0 & 1 & 4 \\
\hline 3 & 0 & 1 & 1 & 4 \\
\hline 4 & 1 & 1 & 0 & 4 \\
\hline 5 & 1 & 1 & 1 & 3 \\
\hline Jumlah & 4 & 3 & 3 & 20 \\
\hline
\end{tabular}

Tabel 5 menunjukkan hasil pengujian pendeteksian daging babi segar. Pada table ini, jumlah dari true positive adalah 4 (empat), jumlah false positif adalah 3 (tiga), jumlah false negative adalah 3 (tiga) dan true negative adalah 20, sehingga dapat dimasukkan nilai tersebut dalam tabel confusion matrix. Tabel confusion matrix dapat dilihat pada Tabel 6 .

Tabel 6.

Confusion Matrix Daging Babi Segar

\begin{tabular}{l|l|l|l}
\hline \multicolumn{2}{c|}{ Negatif } & \multicolumn{2}{c}{ Prediksi } \\
\cline { 3 - 4 } \multicolumn{2}{c|}{ Positif } \\
\hline \multirow{2}{*}{ Aktual } & Negatif & 20 & 3 \\
\cline { 2 - 4 } & Positif & 3 & 4 \\
\hline
\end{tabular}

Maka nilai akurasi dari daging babi segar:

$$
\begin{aligned}
\text { Akurasi } & =\frac{4+20}{4+3+3+20} \\
\text { Akurasi } i & =0.80 \\
\text { Akuras } i & =80 \%
\end{aligned}
$$

Tab el 7.

Hasil Pengujian Pendeteksian Daging Sapi Kurang Segar

\begin{tabular}{l|l|l|l|l}
\hline $\begin{array}{c}\text { Ujicoba } \\
\text { Ke- }\end{array}$ & $\begin{array}{c}\text { True } \\
\text { Positive }\end{array}$ & $\begin{array}{c}\text { False } \\
\text { Positive }\end{array}$ & $\begin{array}{c}\text { False } \\
\text { Negative }\end{array}$ & $\begin{array}{c}\text { True } \\
\text { Negative }\end{array}$ \\
\hline 1 & 1 & 0 & 0 & 5 \\
\hline 2 & 1 & 1 & 1 & 3 \\
\hline 3 & 1 & 1 & 0 & 4 \\
\hline 4 & 1 & 1 & 0 & 4 \\
\hline 5 & 1 & 1 & 1 & 3 \\
\hline Jumlah & 5 & 4 & 2 & 19 \\
\hline
\end{tabular}

Tabel 7 merupakan hasil pengujian pendeteksian daging sapi kurang segar. Menurut Table 7 jumlah dari true positive 
adalah 5 (lima), jumlah false positif adalah 4 (empat), jumlah false negative adalah 2 (dua) dan true negative adalah 19. sehingga kita dapat memasukkan nilai tersebut dalam tabel confusion matrix. Tabel confusion matrix dapat dilihat pada Tabel 8 .

Tabel 8.

Confusion Matrix daging sapi kurang segar

\begin{tabular}{l|l|l|l}
\hline \multicolumn{2}{c}{ Negatif } & \multicolumn{2}{c}{ Prediksi } \\
\cline { 3 - 4 } \multicolumn{2}{c|}{} & Positif \\
\hline \multirow{2}{*}{ Aktual } & Negatif & 20 & 3 \\
\cline { 2 - 4 } & Positif & 3 & 4 \\
\hline
\end{tabular}

Maka nilai akurasi dari daging sapi kurang segar adalah:

$$
\begin{aligned}
\text { Akurasi } & =\frac{5+19}{5+3+3+19} \\
\text { Akurasi } & =0.80 \\
\text { Akurasi } & =80 \%
\end{aligned}
$$

Tabel 9.

Hasil pengujian pendeteksian daging babi kurang segar

\begin{tabular}{l|l|l|l|l}
\hline $\begin{array}{c}\text { Ujicoba } \\
\text { Ke- }\end{array}$ & $\begin{array}{c}\text { True } \\
\text { Positive }\end{array}$ & $\begin{array}{c}\text { False } \\
\text { Positive }\end{array}$ & $\begin{array}{c}\text { False } \\
\text { Negative }\end{array}$ & $\begin{array}{c}\text { True } \\
\text { Negative }\end{array}$ \\
\hline 1 & 1 & 0 & 0 & 5 \\
\hline 2 & 1 & 1 & 1 & 3 \\
\hline 3 & 1 & 0 & 1 & 5 \\
\hline 4 & 1 & 1 & 0 & 4 \\
\hline 5 & 1 & 1 & 0 & 4 \\
\hline Jumlah & 5 & 3 & 2 & 21 \\
\hline
\end{tabular}

Tabel 9 merupakan hasil pengujian pendeteksian daging sapi kurang segar. Menurut Table 9 jumlah dari true positive adalah 5 (lima), jumlah false positif adalah 3 (tiga), jumlah false negative adalah 2 (dua) dan true negative adalah 21, sehingga kita dapat memasukkan nilai tersebut kedalam tabel confusion matrix. Tabel confusion matrix dapat dilihat pada Tabel 10.

Tabel 10.

Confusion Matrix Daging Babi Kurang Segar

\begin{tabular}{l|l|l|l}
\hline \multicolumn{2}{c}{ Negatif } & \multicolumn{2}{c}{ Prediksi } \\
\cline { 3 - 4 } \multicolumn{2}{c|}{} & Positif \\
\hline \multirow{2}{*}{ Aktual } & Negatif & 21 & 2 \\
\cline { 2 - 4 } & Positif & 3 & 5 \\
\hline
\end{tabular}

Maka nilai akurasi dari daging babi kurang segar adalah:

$$
\begin{aligned}
\text { Akurasi } & =\frac{5+21}{5+3+2+21} \\
\text { Akurasi } & =0.83 \\
\text { Akurasi } & =83 \%
\end{aligned}
$$

Tabel 11.

Hasil Pengujian Pendeteksian Daging Sapi Tidak Segar

\begin{tabular}{l|l|l|l|l}
\hline $\begin{array}{c}\text { Ujicoba } \\
\text { Ke- }\end{array}$ & $\begin{array}{c}\text { True } \\
\text { Positive }\end{array}$ & $\begin{array}{c}\text { False } \\
\text { Positive }\end{array}$ & $\begin{array}{c}\text { False } \\
\text { Negative }\end{array}$ & $\begin{array}{c}\text { True } \\
\text { Negative }\end{array}$ \\
\hline 1 & 1 & 0 & 0 & 5 \\
\hline 2 & 1 & 1 & 1 & 3 \\
\hline 3 & 1 & 1 & 0 & 4 \\
\hline 4 & 0 & 1 & 1 & 5 \\
\hline 5 & 1 & 1 & 1 & 3 \\
\hline Jumlah & 4 & 4 & 3 & 20 \\
\hline
\end{tabular}

Tabel 11 merupakan hasil pengujian pendeteksian daging sapi kurang segar. Menurut Tabel 11 jumlah dari true positive adalah 5, jumlah false positif adalah 3, jumlah false negative adalah 2 dan true negative adalah 21. Sehingga kita dapat memasukkan nilai tersebut kedalam tabel confusion matrix. Tabel confusion matrix dapat dilihat pada Tabel 12.

Tabel 12.

Confusion Matrix Daging Sapi Tidak Segar

\begin{tabular}{l|l|l|l}
\hline \multicolumn{2}{c}{ Negatif } & \multicolumn{2}{c}{ Prediksi } \\
\cline { 3 - 4 } \multicolumn{2}{c|}{} & Positif \\
\hline \multirow{2}{*}{ Aktual } & Negatif & 20 & 3 \\
\cline { 2 - 4 } & Positif & 3 & 4 \\
\hline
\end{tabular}

Maka nilai akurasi dari daging sapi tidak segar:

$$
\begin{aligned}
\text { Akurasi } & =\frac{4+20}{4+4+3+20} \\
\text { Akurasi } & =0.77 \\
\text { Akurasi } & =77 \%
\end{aligned}
$$

Tabel 13.

Hasil Pengujian Pendeteksian Daging Babi Tidak

\begin{tabular}{c|l|l|l|l}
\multicolumn{6}{c}{ Segar } \\
\hline $\begin{array}{c}\text { Ujicoba } \\
\text { Ke- }\end{array}$ & $\begin{array}{c}\text { True } \\
\text { Positive }\end{array}$ & $\begin{array}{c}\text { False } \\
\text { Positive }\end{array}$ & $\begin{array}{c}\text { False } \\
\text { Negative }\end{array}$ & $\begin{array}{c}\text { True } \\
\text { Negative }\end{array}$ \\
\hline 1 & 1 & 0 & 0 & 5 \\
\hline 2 & 1 & 1 & 1 & 3 \\
\hline
\end{tabular}


Lanjutan Tabel 13

\begin{tabular}{l|l|l|l|l}
\hline $\begin{array}{c}\text { Ujicoba } \\
\text { Ke- }\end{array}$ & $\begin{array}{c}\text { True } \\
\text { Positive }\end{array}$ & $\begin{array}{c}\text { False } \\
\text { Positive }\end{array}$ & $\begin{array}{c}\text { False } \\
\text { Negative }\end{array}$ & $\begin{array}{c}\text { True } \\
\text { Negative }\end{array}$ \\
\hline 3 & 1 & 0 & 1 & 5 \\
\hline 4 & 1 & 1 & 0 & 4 \\
\hline 5 & 1 & 1 & 0 & 4 \\
\hline Jumlah & 5 & 3 & 2 & 21 \\
\hline
\end{tabular}

Tabel 13 merupakan hasil pengujian pendeteksian daging sapi kurang segar. Menurut Tabel 13 jumlah dari true positive adalah 5 (lima), jumlah false positif adalah 3 (tiga), jumlah false negative adalah 2 (dua) dan true negative adalah 21 . Sehingga kita dapat memasukkan nilai tersebut kedalam tabel confusion matrix. Tabel confusion matrix dapat dilihat pada Tabel 14 .

Tabel 14.

Confusion Matrix Daging Babi Tidak Segar

\begin{tabular}{l|l|l|l}
\hline \multicolumn{2}{c}{ Negatif } & \multicolumn{2}{c}{ Prediksi } \\
\cline { 3 - 4 } \multicolumn{2}{c|}{} & Positif \\
\hline \multirow{2}{*}{ Aktual } & Negatif & 22 & 2 \\
\cline { 2 - 4 } & Positif & 3 & 3 \\
\hline
\end{tabular}

Maka nilai akurasi dari daging babi tidak segar adalah:

$$
\begin{aligned}
& \text { Akurasi }=\frac{4+22}{4+3+3+22} \\
& \text { Akurasi }=0.81 \\
& \text { Akurasi }=81 \%
\end{aligned}
$$

Dari hasil eksperimen didapatkan akurasi daging sapi segar sebesar 79\%, daging babi segar sebesar $80 \%$, daging sapi kurang segar sebesar $80 \%$, daging babi kurang segar $83 \%$, daging sapi tidak segar sebesar $77 \%$, dan daging babi tidak segar sebesar $81 \%$.

\section{SIMPULAN}

Berdasarkan hasil penelitian yang telah dilakukan maka dapat ditarik simpulan bahwa penggunaan sensor TCS3200 dan YL69 memberikan hasil yang cukup baik karena memiliki akurasi Hal tersebut dibuktikan dengan pengujian sensor yang membuahkan hasil data dengan akurasi daging sapi segar sebesar $79 \%$, daging babi segar sebesar $80 \%$, daging sapi kurang segar sebesar $80 \%$, daging babi kurang segar $83 \%$, daging sapi tidak segar sebesar $77 \%$, dan daging babi tidak segar sebesar $81 \%$.

\section{DAFTAR PUSTAKA}

AgroindustrilD, "5 perbedaan Karakteristik Daging Babi dan Daging Sapi," 2017. [Online]. Available: http:// www.agroindustri.id/perbedaankarakteristik-daging-babi-daging-sapi/.

Nugroho, M. F. 2017. “Aplikasi Sensor Warna Dan Sensor Ph Pada Rancang Bangun Alat Pendeteksi Kualitas Daging Sapi Berdasar Warna, Bau dan PH Disusun. Sumatera Selatan: Politeknik Negeri Sriwijaya.

P. E. Pambudi, E. Sutanta, and Mujiman, "Identifikasi Daging Segar Menggunakan Sensor Warna RGB TCS3200DB," J. Teknol. Technoscienta, vol. 6, no. 2, pp. 177-184, 2014.

Prasetyo, A. dan Kendriyanto., 2010. “Kualitas Daging Sapi dan Domba Segar yang disimpan pada Suhu Dingin dengan Pengawet Asap Cair," pp. 843-848, 2010.

R. W. Hadi and I. Setiawan, "Perancangan Alat Pendeteksi Kualitas Daging Sapi Berdasar Warna dan Bau Berbasis Mikrokontroler Atmega32 Menggunakan Logika Fuzzy," vol. 13, no. 1, pp. 21-26, 2011.

Setiawan, R. 2011., “Sistem Pendukung Keputusan untuk menentukan Kelayakan Polisi Dalam Memegang Senjata Api Menggunakan Scoring System," vol. 2011, no. Semantik, 2011.

Simamora, J., "Rancang bangun sistem pendeteksi kesegaran daging berdasarkan sensor bau dan warna," 2017.

Visa, S., Ramsay, B., Ralescu, A., dan Knaap, E. V. D. 2011., "Confusion matrixbased feature selection," CEUR Workshop Proc., vol. 710, pp. 120-127, 2011. 